\title{
Impact of Education on Women Empowerment
}

\author{
Sandeep Kaur Thind ${ }^{1}$, Gopal Singh Bohra ${ }^{2}$ and Himat Kumar ${ }^{3}$ \\ ${ }^{1}$ Community Health Officer, Civil Hospital, Ferozepur, Punjab, India. \\ ${ }^{2}$ Asst. Registrar (Examination), Adesh University, Bathinda, Punjab, India. \\ ${ }^{3}$ Assistant Hospital Administrator, Civil Hospital, Sri Muktsar Sahib, Punjab, India.
}

CITATION: Thind, Sandeep Kaur; Bohra, Gopal Singh and Kumar, Himat (2019), "Impact of Education on Women Empowerment", MERC Global's International Journal of Management, Vol. 7, Issue 4, pp. 276-277.

ARTICLE HISTORY: Submitted: April 22, 2019, Revision received: June 05, 2019, Accepted: June 28,2019

ARTICLE TYPE: Short communication

\begin{abstract}
Women's empowerment is the process for women to redefine gender roles that allow them to acquire the ability to choose among known alternatives otherwise restricted by such ability. The empowerment of women and the achievement of gender equality are vital for our society to ensure the country's sustainable development. Many world leaders and scholars have argued that without gender equality and the empowerment of women, sustainable development is impossible. The present study examines the role of education in women empowerment.
\end{abstract}

KEYWORDS: Women empowerment, Education, Women's movement, Homosexual rights, Disability rights movement.

\section{BIBLIOGRAPHY}

1. Batliwala, Srilatha (1993), Empowerment of Women in South Asia: Concept and Practice, New Delhi: FAO.

2. Bhat, R. A. (2015), "Role of Education in the Empowerment of Women in India", Journal of Education and Practice, Vol. 6, Issue 10, pp. 188-192.

3. Gupta, V. P. (2018), Women Empowerment-Importance, Right and Need, IAS Study Circle, New Delhi.

4. Rao, R. K. (2001), Women and Education, Kalpaz Publications, Delhi.

5. Saha, Tarun (2016), "Impact of Education in Tribal Woman Empowerment: A Case Study of Tribal Woman of Chaupahari Jangal Village in Illambazar Block of Birbhum District, West Bengal", International Research Journal of Interdisciplinary \& Multidisciplinary Studies, Vol. 2, Issue 4.

6. Sharma, B. M. (2004), Women and Education, Commonwealth Publishers, New Delhi. 